\title{
Roles of $1,25(\mathrm{OH})_{2} D_{3}$ and Vitamin
} D Receptor in the Pathogenesis of Rheumatoid Arthritis and Systemic Lupus Erythematosus by Regulating the Activation of CD4 ${ }^{+} \mathrm{T}$ Cells and the PKCS/ ERK Signaling Pathway

\author{
Xiao-Jie He ${ }^{a, b}$ Yan Ding ${ }^{c}$ Wei Xiang ${ }^{c}$ Xi-Qiang Dang ${ }^{a, b}$ \\ aDepartment of Pediatrics, the Second Xiangya Hospital, Central South University, Changsha, \\ 'Laboratory of Pediatric Nephrology, Institute of Pediatrics, Central South University, Changsha, \\ 'Department of Pediatrics, Hainan Provincial Maternal Hospital, Haikou, P.R. China
}

\section{Key Words}

Systemic lupus erythematosus - Rheumatoid arthritis $\cdot 1,25(\mathrm{OH})_{2} \mathrm{D}_{3} \cdot$ Vitamin D receptor • Protein kinase $\mathrm{C} \delta \cdot$ Extracellular signal-regulated kinase $\bullet \mathrm{CD}^{+} \mathrm{T}$ cells

\begin{abstract}
Background/Aims: The study aims to elucidate the roles of $1,25(\mathrm{OH})_{2} \mathrm{D}_{3}$ and vitamin $\mathrm{D}$ receptor (VDR) in in the pathogenesis of rheumatoid arthritis (RA) and systemic lupus erythematosus (SLE) by regulating the activation of CD4 ${ }^{+} \mathrm{T}$ cells and the PKC $\delta / E R K$ signaling pathway. Methods: From January 2013 to December 2015, a total of 130 SLE patients, 137 RA patients and 130 healthy controls were selected in this study. Serum levels of $1,25(\mathrm{OH})_{2} \mathrm{D}_{3}$ and VDR mRNA expression were detected by ELISA and real-time fluorescence quantitative PCR (RT-qPCR). Density gradient centrifugation was performed to separate peripheral blood mononuclear cells (PBMCs). CD4 ${ }^{+} \mathrm{T}$ cells were separated using magnetic activated cell sorting (MACS). CD4 ${ }^{+} T$ cells in logarithmic growth phase were collected and assigned into 9 groups: the normal control group, the normal negative control (NC) group, the VDR siRNA group, the RA control group, the RA NC group, the VDR over-expressed RA group, the SLE control group, the SLE NC group, and the VDR over-expressed SLE group. The mRNA and protein expressions of VDR, PKC $8, E R K 1 / 2, C D 11 a, C D 70$ and CD40L were detected by RT-qPCR and Western blotting. Bisulfite genomic sequencing was conducted to monitor the methylation status of CD11a, CD70 and CD40L. Results: Compared with healthy controls, serum $1,25(\mathrm{OH})_{2} \mathrm{D}_{3}$ level and VDR mRNA expression in peripheral blood were decreased in SLE patients and RA patients. With the increase of concentrations of $1,25(\mathrm{OH})_{2} \mathrm{D}_{3}$ treatment, the VDR mRNA expression and DNA methylation levels of CD11a, CD70 and CD40L were declined, while the expressions of PKC $\delta$, ERK1/2, CD11a, CD70 and CD40L were elevated in SLE, RA and normal CD4 ${ }^{+}$T cells. Compared


with the SLE contro, RA control, SLE NC and RA NC groups, the expressions of PKC, ERK1/2, CD11a, CD70 and CD40L decreased but DNA methylation levels of CD11a, CD70 and CD40L increased in the VDR over-expressed SLE group and VDR over-expressed RA group. However, compared with the normal control and normal NC groups, the expressions of PKC $\delta$, ERK1/2, CD11a, CD70 and CD40L increased, but DNA methylation levels of CD11a, CD70 and CD40L decreased in the VDR siRNA group. Compared with the normal control group, the expressions of PKC, ERK1/2, CD11a, CD70 and CD40L increased, but DNA methylation levels of CD11a, CD70 and CD40L decreased in the SLE control and RA control groups. Conclusion: Our study provide evidence that $1,25(\mathrm{OH})_{2} \mathrm{D}_{3}$ and VDR could inhibit the activation of $\mathrm{CD}^{+} \mathrm{T}$ cells and suppress the immune response of SLE and RA through inhibiting PKC $\delta / E R K$ pathway and promoting DNA methylation of CD11a, CD70 and CD40L.

(C) 2016 The Author(s)

Published by S. Karger AG, Basel

\section{Introduction}

Systemic lupus erythematosus (SLE) is a chronically complex systemic autoimmune disease which affects women 10 times more frequently than men, especially women of child-bearing age [1]. Generally speaking, many organs and tissues in the human body are likely to be involved in SLE, skin, joints, hematopoietic system, kidneys, central nervous system, and heart in particular thereby resulting in a large variety of symptoms [2]. A wide range of factors have been found to be associated with the etiology of this multisystem disease, including genetic predisposition, the influence of female sex hormones as well as such environmental factors as infections and ultraviolet (UV) exposition [3]. Recently, researches demonstrated that abnormalities of B cells (such as B10 cells), T lymphocytes and macrophages have been considered as leading bases of SLE [4, 5]. Current treatments for SLE relies on anti-malarials, steroids, cytotoxic drugs and immunosuppressive agents, which, in spite of their curative effects, lead to a good many deleterious side effects such as therapyresistant disease symptoms and infection [6]. The hallmark of SLE is characterized by the release of autoantibodies which react with self-nuclear and cytoplasmic antigens, resulting in immunologic attacks to body organs [7]. Rheumatoid arthritis (RA) is also a common autoimmune disease which can result in systemic complications, early death, progressive disability and socioeconomic costs [8] A previous study elucidates that deregulation of the mechanisms, which properly control the production of cytokines secreted by $\mathrm{CD} 4^{+} \mathrm{T}$ cells, may indicate a common pathogenic mechanism which underlies the development of RA and SLE [9]. Thus, it is gaining increasing momentum to address the disease from genetic perspective.

It has been reported that abnormalities in $\mathrm{T}$ lymphocytes are frequently found in SLE patients, represented by exaggerated $C D 4^{+} T$ cell activities, the exploration of whose mechanisms has led to the finding of several new defects in signal transduction and thus generated the study on their molecular basis [10]. CD4 ${ }^{+} \mathrm{T}$ cells play a crucial part in the pathology of SLE by actively suppressing the activation and expansion of self-reactive $\mathrm{T}$ cells [11]. The steroid hormone $1,25(\mathrm{OH})_{2} \mathrm{D}_{3}$ regulates gene transcription through a nuclear receptor called vitamin D receptor (VDR) and initiation of rapid cellular responses through a putative plasma membrane-associated receptor $\left(\mathrm{VDR}_{\text {mem }}\right)$ [12]. It has been revealed that the suppression of extracellular signal-regulated kinase (ERK) phosphorylation is sensitive to oestrogen, a female sex hormone that binds to nuclear receptors and alters the rate of gene transcription, in patients with inactive or mild symptoms [13]. Moreover, the disease was found to be related to the expression of protein kinase C (PKC) $\delta$ in SLE monocytes [14]. It has been reported that blocking the PKC $\delta /$ ERK signaling pathway can consequently reduce migration and invasion of human breast carcinoma cells [15]. However, no studies have been carried out to explore the function of molecular in SLE. Therefore, the study aims to explore the roles of $1,25(\mathrm{OH})_{2} \mathrm{D}_{3}$ and VDR in the pathogenesis of RA and SLE by regulating the activation of $\mathrm{CD} 4^{+} \mathrm{T}$ cells and the PKC $\delta /$ ERK signaling pathway.

\section{KARGER}




\section{Cellular Physiology Cell Physiol Biochem 2016;40:743-756

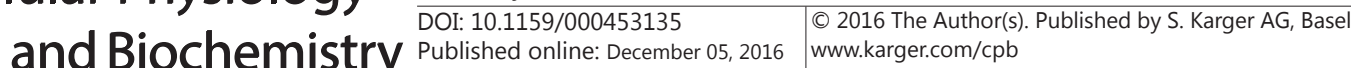 \\ He et al.: Roles of $1,25(\mathrm{OH})_{2} \mathrm{D}_{3}$ and VDR in RA and SLE}

\section{Materials and Methods}

\section{Study subjects}

From January 2013 to December 2015, 130 SLE patients were selected from the Second Xiangya Hospital, Central South University. These SLE patients included 118 females and 12 males with a mean age of $34.32 \pm 12.40$ years (range from 15 to 70 years). All SLE patients were conformed to the diagnostic criteria for SLE of American Rheumatism Association (ARA) and revised in 1997 [16]. Furthermore, a total of 137 RA patients were included as a disease control group (RA group), including 118 females and 19 males with a mean age of $35.98 \pm 12.24$ years (range from 16 to 70 years), excluded of other systemic diseases). All RA patients were conformed to the diagnostic criteria for RA of American College of Rheumatology (ACR) and European League Against Rheumatism (EULAR) [17]. Meanwhile, 130 healthy controls underwent physical examination were selected, including 121 females and 9 males with a mean age of $33.35 \pm 11.03$ years (range from 16 to 72 years). This study was approved by the Ethics Committee of the Second Xiangya Hospital, Central South University, and informed consent was obtained from all study subjects.

\section{ELISA assay}

Venous blood $(4 \mathrm{ml}$ ) was collected from all subjects, with $2 \mathrm{ml}$ peripheral blood for PCR detection of VDR mRNA expression, $2 \mathrm{ml}$ placed in refrigerator for $30 \sim 60 \mathrm{~min}$ at $4^{\circ} \mathrm{C}$. The blood was centrifuged for $15 \mathrm{~min}$ at a speed of $3000 \mathrm{rpm}$ after coagulation. Supernatant was collected cautiously for detection of serum $1,25(\mathrm{OH})_{2} \mathrm{D}_{3}$ level. Serum $1,25(\mathrm{OH})_{2} \mathrm{D}_{3}$ levels in healthy controls, RA patients and SLE patients were detected strictly in accordance with ELISA kit (purchased from Westang Biotechnology Co., Ltd., Shanghai, China). Firstly, 10 standard holes were set in enzyme-labeled coated plate where samples were treated with gradient dilution to draw standard curve. Samples to be detected were added into holes on enzyme-labeled coated plate and got mixed with gentle shake before being incubated for $30 \mathrm{~min}$ at $37^{\circ} \mathrm{C}$. Liquid in holes was removed, and cleaning solution was added to rinse it for $30 \mathrm{~s}$, which was repeated for 5 times before drying the holes; enzyme-labeled reagent of $50 \mu \mathrm{l}$ was added to incubate for $30 \mathrm{~min}$ at $37^{\circ} \mathrm{C}$; liquid in holes was removed, and cleaning solution was added to rinse it for $30 \mathrm{~s}$, which was repeated for 5 times before drying the holes; chromogenic agent $\mathrm{A}$ and $\mathrm{B}$ of $50 \mu \mathrm{l}$ each were added successively and was incubated in dark place for $15 \mathrm{~min}$ at $37^{\circ} \mathrm{C}$ after mixture, ending with $50 \mu \mathrm{l}$ elimination agent. Blank holes were used for zero setting and optical density (OD) value $(450 \mathrm{~nm}$ ) in each hole was detected using microplate reader (BioRad Company, USA) within 15 min. After that, standard curve was drawn with concentration of standard samples as abscissa and OD value as ordinate, followed by counting the corresponding concentration of samples with their OD value plugged in the standard curve equation.

\section{$C D 4^{+} T$ cells isolation and culture}

Peripheral blood of $5 \mathrm{ml}$ was collected from healthy controls, RA patients and SLE patients and mixed evenly with Phosphate Buffered Saline (PBS). Appropriate amount of lymphocyte separation solution (Sigma Company) was added. It was centrifuged horizontally at $18^{\circ} \mathrm{C}$ for $30 \mathrm{~min}$ at a speed of $2000 \mathrm{rpm}$, dividing it into 3 layers. White mist layer in the interface between upper layer and middle layer was extracted with caution into centrifuge tube. PBS of 5 times larger size was used to rinse mononuclear cells which were later centrifuged for $10 \mathrm{~min}$ at $1600 \mathrm{rpm}$. With supernatant removed, the rinse procedure was carried out again. PBS of $1 \mathrm{ml}$ was used to resuspend cells, one drop of which was placed on cell counting chamber for counting. Mononuclear cells suspension weighing $400 \mathrm{~g}$ was centrifuged for $10 \mathrm{~min}$ at $4^{\circ} \mathrm{C}$, after which, with supernatant abandoned, $1 \times 10^{7}$ cells were selected to be added into $80 \mu \mathrm{l}$ magnetic activated cell sorting (MACS) buffer and $20 \mu \mathrm{l}$ MACS CD4 superbead (MiltenyiBiotec Company) for incubation for $15 \mathrm{~min}$ at $4^{\circ} \mathrm{C}$. Next, 1 2ml MACS buffer was added to rinse cells weighing $300 \mathrm{~g}$, followed by 10 min centrifugation, with supernatant abandoned, $500 \mu \mathrm{l}$ MACS buffer was added to resuspend cells which were later placed in LS separator column and were classified in MiniMACS separator. LS separator column was rinsed with 500 $\mu \mathrm{l}$ buffer for 3 times and $1 \mathrm{ml}$ MACS buffer was used to separate CD4+T cells from LS column when it was removed from magnetic field. CD4+T cells selected with MACS were added into RPMI-1640 culture medium containing 10\% fetal bovine serum (FBS) (Hyclone Company) and 1\% mycillin (Hyclone Company), and placed in $5 \% \mathrm{CO}_{2}$ incubator at $37^{\circ} \mathrm{C}$ for incubation. As to $\mathrm{CD} 4^{+} \mathrm{T}$ cell detection, CD4-FITC-labeled antibody (eBioscience Company) was added into CD4 ${ }^{+} \mathrm{T}$ cells extracted with MACS, which was incubated in the dark at room temperature for $30 \mathrm{~min}$ after mixture. PBS of $2 \mathrm{ml}$ was employed to resuspend cells which 


\section{Cellular Physiology Cell Physiol Biochem 2016;40:743-756

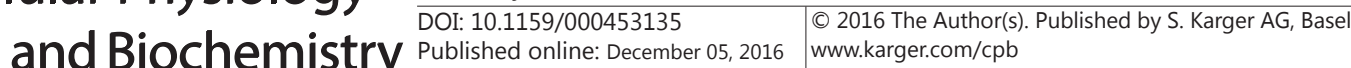 \\ He et al.: Roles of $1,25(\mathrm{OH})_{2} \mathrm{D}_{3}$ and VDR in RA and SLE}

were centrifuged for $5 \mathrm{~min}$ at $1000 \mathrm{rpm}$. With supernatant abandoned, appropriate amount of flow buffer solution was used for resuspension and selected CD4+T cells purity was detected using flow cytometry (Becton Dickinson Company).

$C D 4^{+} T$ cells treated with different dose of $1,25(\mathrm{OH})_{2} D_{3}$

Absolute ethanol was added into $1,25(\mathrm{OH})_{2} \mathrm{D}_{3}$ (Sigma Company) solution with an initial concentration of $1 \times 10^{-3} \mathrm{mmol} / \mathrm{L}$, which was diluted into 4 concentration gradient: $1 \times 10^{-6} \mathrm{mmol} / \mathrm{L}, 1 \times 10^{-7} \mathrm{mmol} / \mathrm{L}$, $1 \times 10^{-8} \mathrm{mmol} / \mathrm{L}$ and $1 \times 10^{-9} \mathrm{mmol} / \mathrm{L}$. CD4 ${ }^{+} \mathrm{T}$ cells in SLE group and control group were mixed fully with RPMI-1640 culture medium (Hyclone Company) containing 10\% FBS (Hyclone Company) and 1\% mycillin (Hyclone Company), after which, $1 \mathrm{ml}$, some $10^{6}$ cells, was transplanted into each hole on 24-hole culture plate. In RPMI-1640 culture medium, $1,25(\mathrm{OH})_{2} \mathrm{D}_{3}$ of $0 \mathrm{mmol} / \mathrm{L}, 1 \times 10^{-6} \mathrm{mmol} / \mathrm{L}, 1 \times 10^{-7} \mathrm{mmol} / \mathrm{L}, 1 \times$ $10^{-8} \mathrm{mmol} / \mathrm{L}$ and $1 \times 10^{-9} \mathrm{mmol} / \mathrm{L}$ was added respectively, and it was placed at $37^{\circ} \mathrm{C}$ in $5 \% \mathrm{CO}_{2}$ incubator (SANYO Company, Japan) to incubate for $72 \mathrm{~h}$.

Construction of human VDR cDNA overexpression vector

Total RNA in healthy controls was extracted using Trizol and human VDR cDNA was obtained using Reverse Transcription-Polymerase Chain Reaction (RT-PCR). Forward primer (CAA CCA AGA CTA CAA GTA CCG CGT CAG TGA) and reverse primer (AAC CAG CGG GAA GAG GTC AAG GG) synthesized by Sangon Biotech Co., Ltd., Shanghai were employed for PCR amplification, after which, obtained PCR products received agarose gel electrophoresis and target segments were cut from gel. QIAquick PCR purification recovery kit (QIAGEN Company) was used for purification recovery, after which, purified and recovered VDR cDNA was instilled into pcDNA3.1 vector that had been cut by Hind III and Xho I enzymes. Products were connected to be transformed into Escherichia coli DH5 $\alpha$ competent cells, which were cultured on culture plates containing ampicillin for one night at $37^{\circ}$. The next day, colony in single colony was selected for PCR and sequencing, the result of which was compared to National Center of Biotechnology Information (NCBI) VDR sequences, so as to substantiate VDR gene sequences' presence in high expressed plasmids.

\section{Construction of VDR-siRNA interference vector}

According to sequences of VDR cDNA in GenBank, the Basic Local Alignment Search Tool (BLAST) software was used to design VDRsiRNA sequences. In conformity with requirements of enzyme restriction site of PLKO.1-sP6-GFP, expression plasmids of siRNA, sequences encoding siRNA cDNA were synthesized, whose structure was Age I + positive-sense strand (5'-TGC TGA ACA TGA TCA CCT CAA TGG CAG TTT GGC CAC TGA CTG ACT GCC ATT GGT GAT CAT GTT-3') + loop + antisense strand (5'-CCT GAA CAT GAT CAC CAA TGG CAG TCA GTC AGT GGC CAA AAC TGC CAT TGA GGT GAT CAT GTTC-3') + termination signal + EcoR I, with strands synthesized by GenePharma Company, Shanghai. Expression plasmids of VDR siRNA that had been successfully constructed were transferred to Escherichia coli DH5 $\alpha$ competent cells before being cultured in culture plates containing ampicillin for one night at $37^{\circ} \mathrm{C}$. The next day, monoclonal colony was selected for scale-up culture. Eventually, regular-PCR was used for detection with U6: 5'-ATT TGC GTG TCA TCC TTGCG-3' and Sp6: 5'-AAT TTA GGT GAC ACT ATAG-3' employed as detection primers, after which, plasmids shown correct in detection were sent to BGI TECH SOLUTIONS CO., LTD. (Shenzhen, China) for sequencing.

\section{Cell transfection and grouping}

CD4+T cells in logarithmic growth phase were collected and assigned into 9 groups: the normal control group (normal CD4+T cells without any transfection), the normal negative control (NC) group (normal CD4 ${ }^{+} \mathrm{T}$ cells transfected with empty vector plasmid), the VDR siRNA group (normal CD4 ${ }^{+} \mathrm{T}$ cells transfected with VDR siRNA expression plasmid), the RA control group (RA CD4+T cells without any transfection), the RA NC group (RA CD4 ${ }^{+}$T cells transfected with empty plasmid), the VDR over-expressed RA group (RA $\mathrm{CD}^{+} \mathrm{T}$ cells transfected with VDR overexpression vector), the SLE control group (SLE CD4+T cells without any transfection), the SLE NC group (SLE CD4+T cells transfected with empty vector plasmid), and the VDR over-expressed SLE group (SLE CD4+T cells transfected with VDR expression vector). With $0.25 \%$ trypsin digestion and centrifugation for $5 \mathrm{~min}$ at $1000 \mathrm{r} / \mathrm{min}$, they were resuspended in culture medium, and $5 \times$ $10^{6}$ cells were added into $2 \mathrm{~mm}$ electric cup, followed by addition of $10 \mu \mathrm{g}$ VDR overexpression vector and VDR-siRNA respectively. With voltage set at $500 \mathrm{~V}$ and electroporation performed at $1 \mathrm{~ms}$, it was next placed 


\section{Cellular Physiology Cell Physiol Biochem 2016;40:743-756 \begin{tabular}{l|l|l} 
and BOI: 10.1159/000453135 & $\begin{array}{l}\text { (C) 2016 The Author(s). Published by S. Karger AG, Basel } \\
\text { www.karger.com/cpb }\end{array}$
\end{tabular} \\ He et al.: Roles of $1,25(\mathrm{OH})_{2} \mathrm{D}_{3}$ and VDR in RA and SLE}

Table 1. Primers sequences for reverse transcription-polymerase chain reaction (RT-PCR). VDR, Vitamin D receptor; PKC $\delta$, protein kinase $\mathrm{C} \delta$; ERK1/2, extracellular signal-regulated kinase $1 / 2 ; \mathrm{F}, \mathrm{PKC} \delta$ forward; $\mathrm{R}$, reverse

\begin{tabular}{ll}
\hline Gene & \multicolumn{1}{c}{ Sequence $\left(5^{\prime}-3^{\prime}\right)$} \\
\hline VDR & F: CAACCAAGACTACAAGTACCGCGTCAGTGA \\
& R: AACCAGCGGGAAGAGGTCAAGGG \\
PKC $\delta$ & F: GTCATCCAGATTGTGCTAATGCG \\
& R: TCTTGTGGATGGCAGCGTTCA \\
ERK1/2 & F: GCAAGCACTACCTGGATCAGCTC \\
& R: TCGGGCCTTCATGTTGATGATA \\
CD11a & F: TGAGAGCAGGCTATTTGGGTTAC \\
& R: CGGCCCATGTGCTGGTAT \\
CD70 & F: TGCTTTGGTCCCATTGGTCG \\
& R: TCCTGCTGAGGTCCTGTGTGATTC \\
CD40L & F: AAAGGAAAGTTTGGAAGTGAAT \\
& R: TGAGTAAGGTGGTTATTTTGATAGT \\
$\beta$-actin & F: GCACCACACCTTCTACAATGAGC \\
& R: GGATAGCACAGCCTGGATAGCAAC \\
\hline
\end{tabular}

statically for $10 \mathrm{~min}$ at $4^{\circ} \mathrm{C}$, after which, RPMI-1640 culture medium containing $10 \%$ serum was added to culture for another $24 \mathrm{~h}$. Electrotransfer was purchased from Bio-Rad Company. During the process of culture, cell morphology was observed under inverted phase contrast microscope (OLYMPUS Company).

Real-time fluorescence quantitative PCR (RT-qPCR)

With CD4+T cells collected from each group, total RNA was extracted using Trizol. RNA of 500 ng was selected for reverse transcription in accordance with instructions on Reverse Transcription System A3500 reverse transcription kit purchased from Promega Compay. According to gene sequences released publically by Genbank, Primer 5.0 was employed to design primers included in Table 1 respectively which were synthesized by Sangon Biotech Co., Ltd., Shanghai. Reaction condition for RT-qPCR (SYBR GREEN method): 1) at $95^{\circ} \mathrm{C}$ for $15 \mathrm{~min}$ once; 2) at $95^{\circ} \mathrm{C}$ for $30 \mathrm{~s}$, at $55^{\circ} \mathrm{C}$ for $45 \mathrm{~s}$, at $72^{\circ} \mathrm{C}$ for $1 \mathrm{~min}, 40$ times; reaction system: Premix Ex Taq or SYBR Green Mix $12.5 \mu \mathrm{l}$, Forward Primer $1 \mu \mathrm{l}$, Reverse Primer $1 \mu \mathrm{l}$, DNA template 1-4 $\mu \mathrm{l}$ and $\mathrm{ddH}_{2} \mathrm{O}$ up to $25 \mu$ l. With glyceraldehyde phosphate dehydrogenase (GAPDH) as internal control gene and the standard for control group set at 1 , Ct values of target genes (inflection point of amplification power curve) were obtained and Relative Quantification (RQ) values of target genes were calculated for statistical analysis in accordance with $\mathrm{RQ}=2^{-\Delta \Delta C t}$. RT-qPCR equipment, whose model number was iQ5, was purchased from BioRad Company.

\section{Western blotting}

$\mathrm{CD}^{+} \mathrm{T}$ cell protein was collected from each group and its concentration was examined based on bicinchoninic acid (BCA) kit (Beyotime Biotechnology Research Institute). $5 \times$ loading buffer (Beyotime Biotechnology Research Institute) was added into protein and boiled for $10 \mathrm{~min}$ at $95^{\circ} \mathrm{C}$. Samples of $30 \mu \mathrm{g}$ were placed into each hole, and electrophoresis (Bio-RAD Company) with 10\% polyacrylamide gel (Boster Company, Wuhan) was used for separation. Trarsmembrane was performed with Polyvinylidene Fluoride (PVDF) (Amresco Company), and it was kept sealed off at room temperature for $1 \mathrm{~h}$ with 5\% bovine serum albumin (BSA) (Sino-American Biotechnology Co., Ltd., Beijing). Tris-Buffered Saline and Tween 20 (TBST) (Biomics Laibo Technology Co., Ltd., Beijing), diluted primary antibody of $\beta$-actin (ab8226, 1: 1000), VDR (ab8756, 1: 100), pPKC $\delta$ (ab76181, 1: 2500) and pERK1/2 (ab54230, $1 \mu \mathrm{g} / \mathrm{ml}$ ), which were purchased from Abcam Company and kept for one night at $4^{\circ} \mathrm{C}$. Membrane was rinsed with TBST for three times, 5 min each time. Secondary antibody (Abcam Company) was added for reaction at $37^{\circ} \mathrm{C}$ for $2 \mathrm{~h}$. Membrane was rinsed and chromogenic reagent of substrate A was mixed with B in 1: 1 ratio (Promega Company) for developing at room temperature for $1 \mathrm{~min}$. Then, it, wrapped up with preservative film, was transferred to dark room, and received developing and photographic fixing with X-ray after exposure. Gel-Pro analyzer 4.0 was used to analyze bands and target protein expression level was presented in grey value ratio of target protein to $\beta$-actin.

Flow cytometry

With mononuclear cells isolated from peripheral blood, mononuclear cells of $10^{6} / \mathrm{L}$ were selected from SLE group and control group respectively. Cells of $100 \mu \mathrm{l}$ were added into flow cytometry tube where antibodies labeled by $20 \mu \mathrm{l}$ of CD4-PE+CD11a-FITC, CD4-PE+CD70-FITC, CD4-PE+CD40L-FITC respectively 


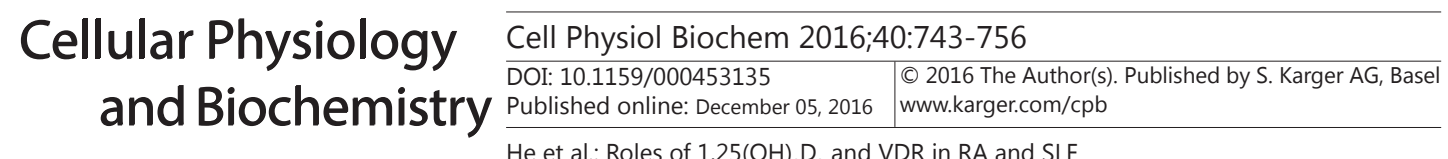

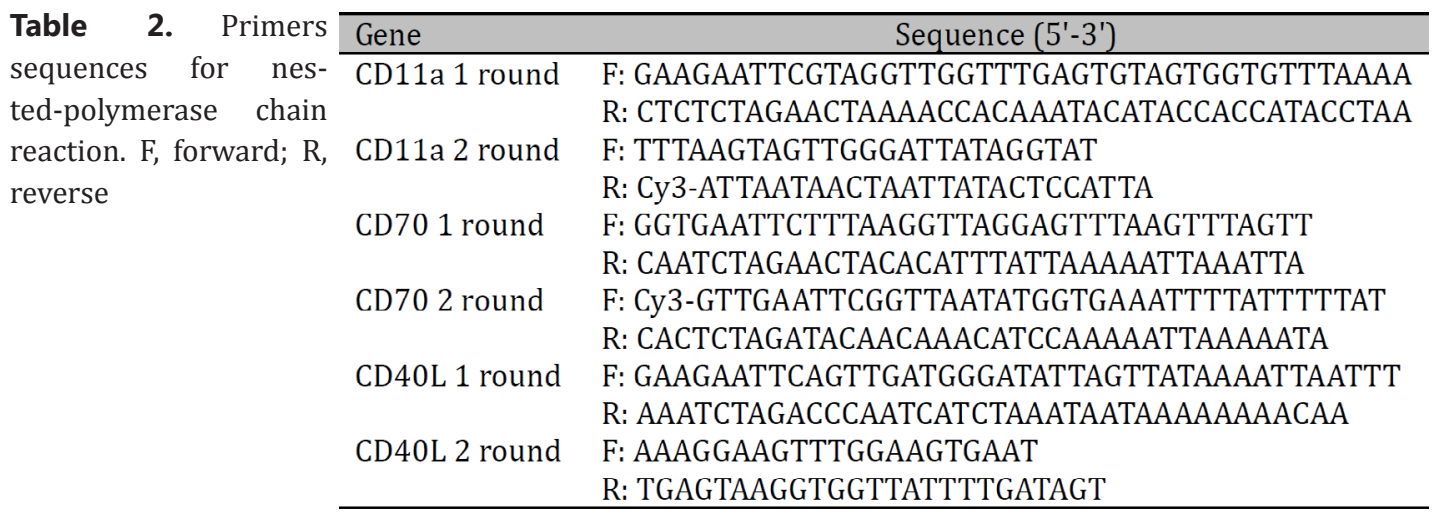

(eBioscience Company) were added. In control tube of the same type, $20 \mu \mathrm{l} \mathrm{CD4-PE,} \mathrm{CD11a-FITC,} \mathrm{CD70-}$ FITC and CD40L-FITC were added respectively, each repeated 5 times and incubated in the dark at room temperature for $3 \mathrm{~min}$ after even mixture. PBS of $2 \mathrm{ml}$ was used to resuspend cells which were centrifuged at $1000 \mathrm{rpm}$ for $5 \mathrm{~min}$. Supernatant abandoned, appropriate amount of flow buffer solution was used for resuspension and CD11a, CD70 and CD40L protein expressions were detected using flow cytometry (Becton Dickinson Company).

Bisulfite genomic sequencing

Blood/tissue/genomic DNA extraction kit (TIANamp Genomic DNA Kit) was used to extract CD4+T cells in SLE patients and control group respectively, the DNA of which received Sodium Bisulfite with EpiTectBisufite kit (Qiagen Company) in strict accordance with instructions on kit. Then, nested PCR was carried out, employing Go Taq hot star polymerase System of Promega Company, and nested PCR primers could be seen in Table 2. PCR products underwent agarose gel electrophoresis, and agar gel with target band was cut under ultraviolet lamp, followed by purification recovery of DNA using QIAquick Gel Extraction Kit of Qiagen Company. After that, pGEM-T Easy Vector Systems (Promega Company) were employed to connect purification-recovered nested PCR products to T Vector, which were transformed into Escherichia coli DH5 $\alpha$ competent cells. Positive colonies were filtered based on blue-white screening, where plasmids were extracted using QIAprepMiniprep Kit (Qiagen Company) and sent to BGI TECH SOLUTIONS CO., LTD. (Shenzhen, China) for sequencing.

\section{Statistical analysis}

Statistical software of SPSS 21.0 (SPSS Inc., Chicago, IL, USA) was employed for statistical analysis of data, with measurement data presented in mean \pm standard deviation ( $\overline{\mathrm{x}} \pm \mathrm{s}$ ). Independent sample $t$ test was employed for the comparison between groups while One-Way analysis of variance (ANOVA) with least significant difference (LSD)-t was used for comparison among groups, $P<0.05$ being statistically significant.

\section{Results}

Baseline characteristics of healthy controls, RA patients and SLE patients

The baseline characteristics of the healthy controls, RA patients and SLE patients were shown in Table 3. No significant difference was revealed in age, height and weight among healthy controls, RA patients and SLE patients (all $P>0.05$ ). The body mass index (BMI) was also not significantly different among healthy controls, RA patients and SLE patients $(P>0.05)$.

Comparisons of serum 1,25(OH) $D_{3}$ level and VDR mRNA expression among healthy controls, RA patients and SLE patients

Serum $1,25(\mathrm{OH})_{2} \mathrm{D}_{3}$ levels and VDR mRNA expressions of RA patients and SLE patients were significantly lower than those of healthy controls (all $P<0.05$ ). However, there was no 
He et al.: Roles of $1,25(\mathrm{OH})_{2} \mathrm{D}_{3}$ and VDR in RA and SLE

Table 3. Baseline characteristics of healthy controls, RA patients and SLE patients. RA: rheumatoid arthritis; SLE: systemic lupus erythematosus; BMI: body mass index

\begin{tabular}{lcccc}
\hline Characteristic & $\begin{array}{c}\text { Healthy control } \\
(\mathrm{n}=130)\end{array}$ & $\begin{array}{c}\text { RA patients } \\
(\mathrm{n}=137)\end{array}$ & $\begin{array}{c}\text { SLE patients } \\
(\mathrm{n}=130)\end{array}$ & $P$ \\
\hline Age (years) & $33.35 \pm 11.03$ & $35.98 \pm 12.24$ & $34.32 \pm 12.40$ & 0.191 \\
Gender (Male / Female) & $9 / 121$ & $19 / 118$ & $12 / 118$ & 0.157 \\
Height $(\mathrm{m})$ & $1.62 \pm 0.07$ & $1.64 \pm 0.08$ & $1.62 \pm 0.08$ & 0.085 \\
Weight $(\mathrm{kg})$ & $55.81 \pm 9.43$ & $55.37 \pm 9.79$ & $53.68 \pm 9.74$ & 0.171 \\
BMI $\left(\mathrm{kg} / \mathrm{m}^{2}\right)$ & $21.30 \pm 4.13$ & $20.72 \pm 4.11$ & $20.59 \pm 4.29$ & 0.345 \\
\hline
\end{tabular}

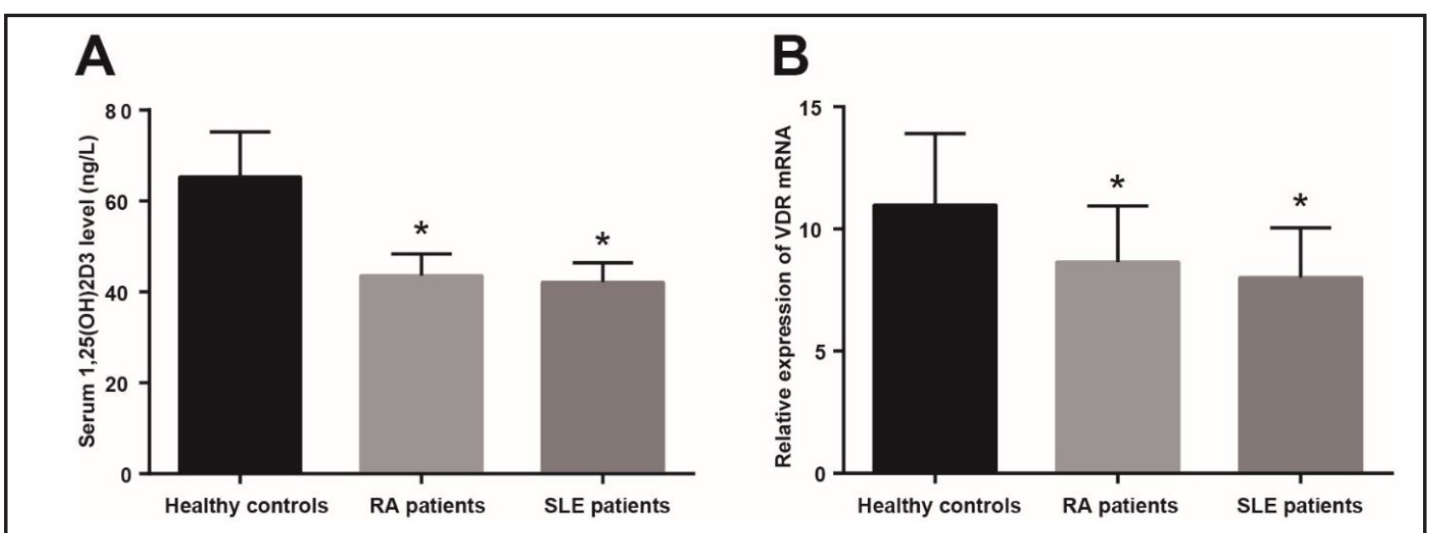

Fig. 1. Comparisons of serum 1,25(OH)2D3 levels and VDR mRNA expression of healthy controls, RA patients and SLE patients. Note: (A) Serum 1,25(OH)2D3 levels in healthy controls, RA patients and SLE patients detected by ELISA; (B) VDR mRNA expressions in healthy controls, RA patients and SLE patients detected by real-time fluorescence quantitative PCR (RT-qPCR); ${ }^{*} P<0.05$ compared with control group.

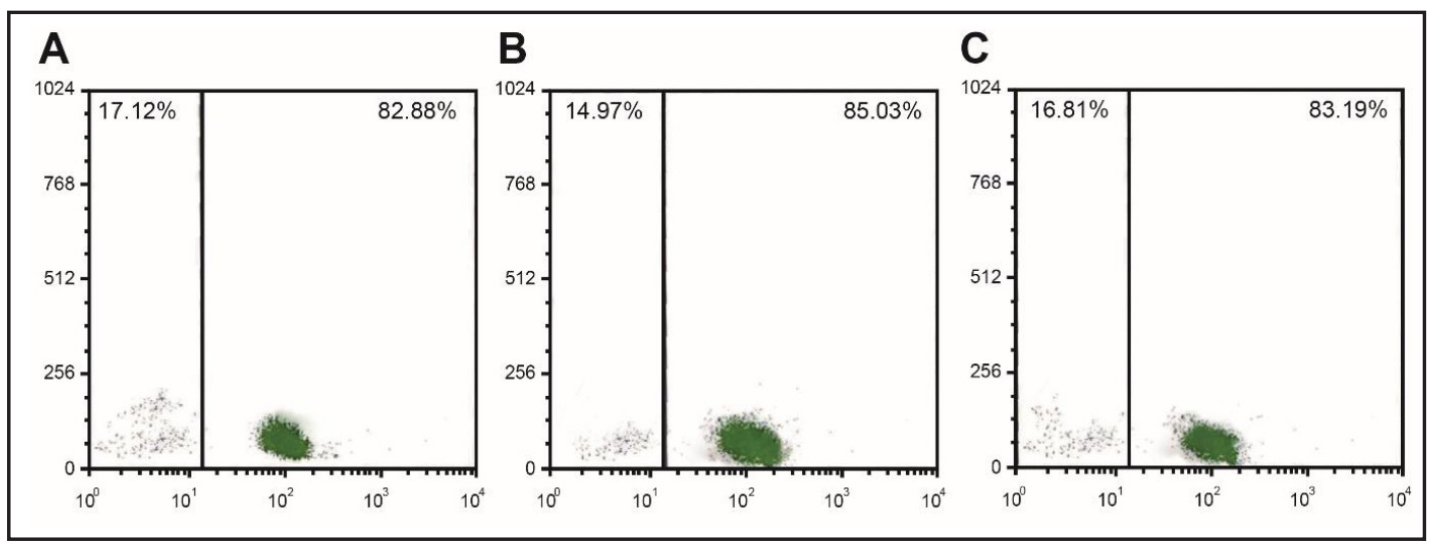

Fig. 2. Scatter plots of CD4+ T cells separated using magnetic activated cell sorting (MACS) and detected by flow cytometry. Note: (A) Normal CD4+ T cells; (B) RA CD4+ T cells; (C) SLE CD4+ T cells; RA, rheumatoid arthritis; SLE, systemic lupus erythematosus.

difference in serum $1,25(\mathrm{OH})_{2} \mathrm{D}_{3}$ levels and VDR mRNA expressions between RA patients and SLE patients (both $P>0.05$ ) (Fig. 1).

Identification of normal CD4 $4^{+} T$ cells, RA CD $4^{+} T$ cells and SLE CD4 $4^{+} T$ cells

$\mathrm{CD} 4^{+} \mathrm{T}$ cells sorted out from MACS were labeled with anti-CD4-FITC flow monoclonal fluorescent antibody and CD $4^{+} \mathrm{T}$ cell purity was detected by flow cytometry. Normal CD $4^{+} \mathrm{T}$ cell purity was $82.88 \%$, RA CD4 ${ }^{+} \mathrm{T}$ cell purity was $85.03 \%$ and SLE CD4 ${ }^{+} \mathrm{T}$ cell purity was $83.19 \%$ by FCS express V3 software analysis (Fig. 2).

\section{KARGER}




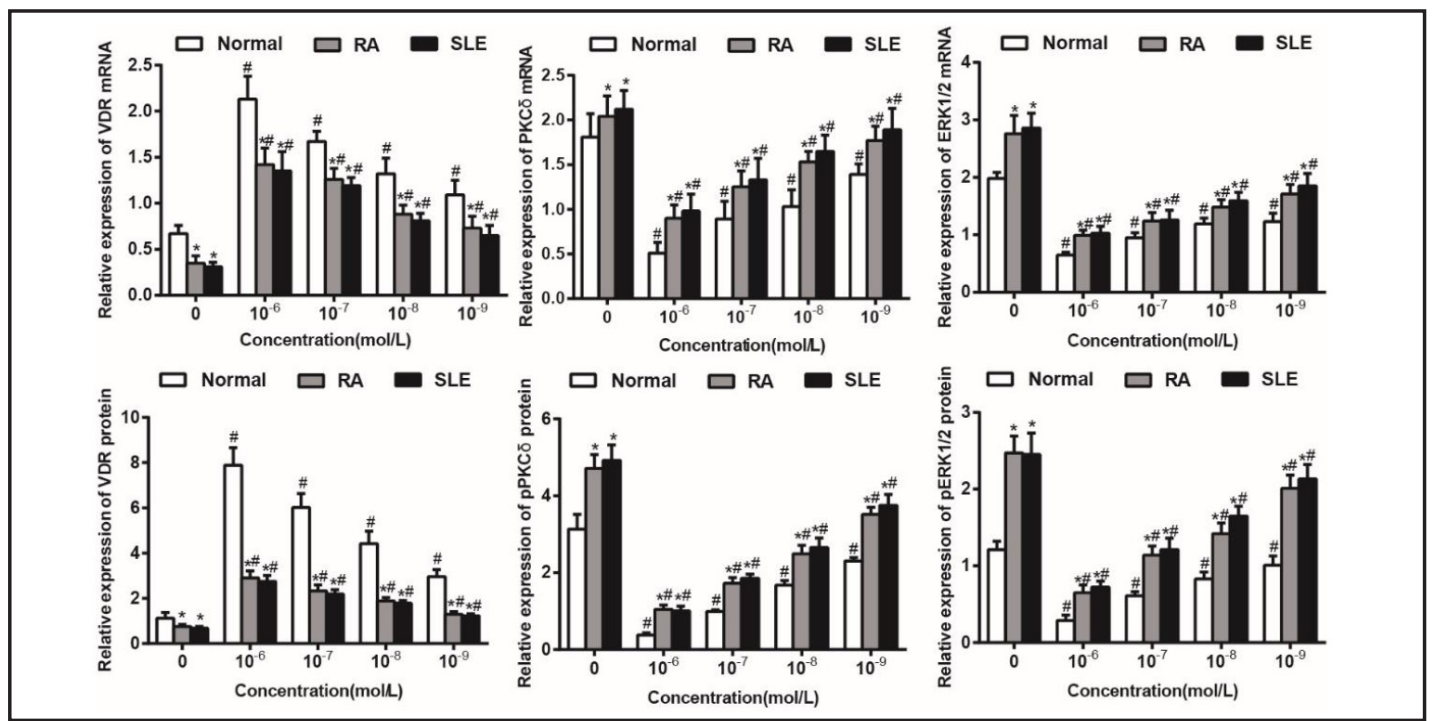

Fig. 3. The mRNA and protein expressions of VDR, PKC $\delta$ and ERK1/2 in normal CD $4^{+} \mathrm{T}$ cells, RA CD4+ ${ }^{+}$cells and SLE CD4 ${ }^{+} \mathrm{T}$ cells after treated with different doses of $1,25(\mathrm{OH})_{2} \mathrm{D}_{3}$ detected by RT-qPCR and Western blotting. Note: *, $P<0.05$ compared with normal CD4+ T cells at the same doses of $1,25(\mathrm{OH})_{2} \mathrm{D}_{3} ; \#, P<0.05$ compared with SLE CD4+ ${ }^{+}$cells treated with $0 \mathrm{~mol} / \mathrm{l} 1,25(\mathrm{OH})_{2} \mathrm{D}_{3}$.
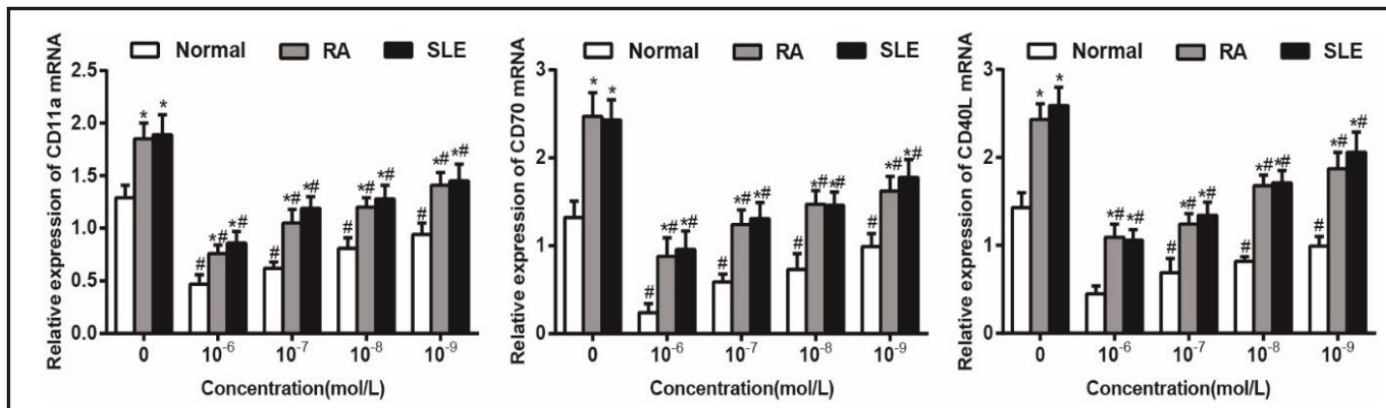

Fig. 4. The mRNA expressions of CD11a, CD70, and CD40L in normal CD4+ $\mathrm{T}$ cells, RA CD4 ${ }^{+} \mathrm{T}$ cells and SLE $\mathrm{CD}^{+}{ }^{+} \mathrm{T}$ cells after treated with different doses of $1,25(\mathrm{OH})_{2} \mathrm{D}_{3}$ detected by RT-qPCR. Note: ${ }^{*}, P<0.05$ compared with normal CD4+ $\mathrm{T}$ cells at the same doses of $1,25(\mathrm{OH})_{2} \mathrm{D}_{3} ; \#, P<0.05$ compared with SLE CD4 ${ }^{+} \mathrm{T}$ cells treated with $0 \mathrm{~mol} / \mathrm{l} 1,25(\mathrm{OH})_{2} \mathrm{D}_{3}$.

Expressions of VDR, PKC $\delta$ and ERK1/2 in $C D 4^{+} T$ cells treated with different doses of $1,25(\mathrm{OH})_{2} D_{3}$

All $\mathrm{CD}^{+} \mathrm{T}$ cells were treated with $0,10^{-6}, 10^{-7}, 10^{-8}$, and $10^{-9} \mathrm{~mol} / \mathrm{L} 1,25(\mathrm{OH})_{2} \mathrm{D}_{3^{\prime}}$, respectively. The results showed that VDR expressions in normal/RA/SLE CD4+T cells increased with the increase doses of $1,25(\mathrm{OH})_{2} \mathrm{D}_{3}$, and reached a stable stage at $10^{-6} \mathrm{~mol} / \mathrm{L}$. VDR expressions in SLE CD $4^{+} \mathrm{T}$ cells and RA CD $4^{+} \mathrm{T}$ cells were lower than those in normal CD $4^{+}$ T cells (all $P<0.05$ ). However, PKC $\delta$ and ERK1/2 expressions decreased with the increase doses of $1,25(\mathrm{OH})_{2} \mathrm{D}_{3}$, and also reached a lowest level at $10^{-6} \mathrm{~mol} / \mathrm{L}$. PKC $\delta$ and ERK1/2 expressions in SLE CD4 ${ }^{+} \mathrm{T}$ cells and RA CD4 ${ }^{+} \mathrm{T}$ cells were higher than those in normal $\mathrm{CD} 4^{+} \mathrm{T}$ cells (all $P<0.05$ ). However, there were no significant differences between SLE CD $4^{+} \mathrm{T}$ cells and RA CD $4^{+}$T cells in the expressions of VDR, PKC $\delta$ and ERK1/2 after treated with same doses of $1.25(\mathrm{OH})_{2} \mathrm{D}_{3}$ (all $P>0.05$ ) (Fig. 3).

The mRNA expressions of CD11a, CD70 and CD40L in CD4+ $T$ cells treated with different doses of $1,25(\mathrm{OH})_{2} D_{3}$

In comparison with $\mathrm{CD} 4+\mathrm{T}$ cells treated with $0 \mathrm{~mol} / \mathrm{L} 1.25(\mathrm{OH})_{2} \mathrm{D}_{3}$, the mRNA expressions of CD11a, CD70 and CD40L decreased in normal/RA/SLE CD4+T cells after 

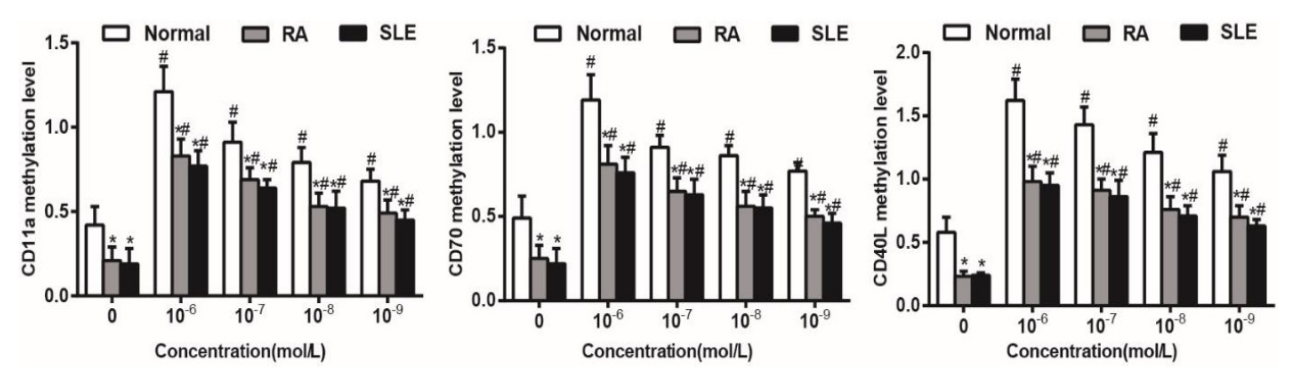

Fig. 5. DNA methylation levels in transcriptional regulation region of CD11a, CD70, and CD40L in CD4 ${ }^{+}$ $\mathrm{T}$ cells in normal $\mathrm{CD} 4^{+} \mathrm{T}$ cells, RA CD4 ${ }^{+} \mathrm{T}$ cells and SLE CD4 ${ }^{+} \mathrm{T}$ cells after treated with different doses of 1,25(OH)2D3 detected by Bisulfite genomic sequencing. Note: ${ }^{*}, P<0.05$ compared with normal CD4 ${ }^{+} \mathrm{T}$ cells at the same doses of $1,25(\mathrm{OH})_{2} \mathrm{D} 3 ; \#, P<0.05$ compared with SLE CD4 ${ }^{+} \mathrm{T}$ cells treated with 0 mol/l 1,25(OH)2D3.

Fig. 6. The mRNA and protein expressions of PKC $\delta$ and ERK1/2 in $\mathrm{CD}^{+} \mathrm{T}$ cells after transfected with VDR overexpression vector and VDR siRNA vector. Note: *, $P<0.05$ compared with the VDR siRNA group; \#, $P<0.05$ compared with the VDR overexpressed RA and overexpressed SLEA group.
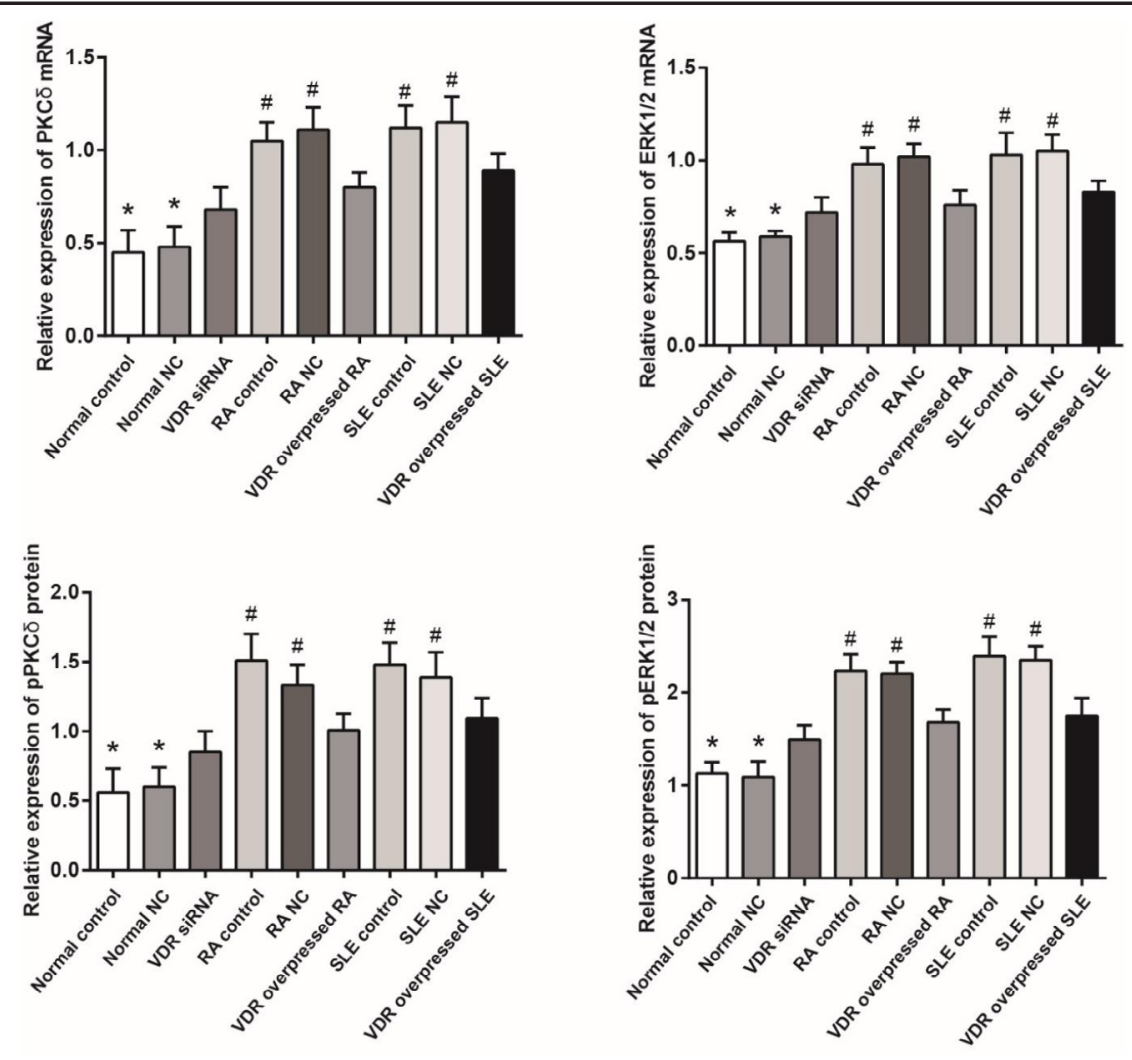

treated with other doses of $1,25(\mathrm{OH})_{2} \mathrm{D}_{3}$, in which those expressions were lowest after treated with $10^{-6} \mathrm{~mol} / \mathrm{L} 1.25(\mathrm{OH})_{2} \mathrm{D}_{3}$. The mRNA expressions of CD11a, CD70, CD40L expressions in SLE CD4 ${ }^{+} \mathrm{T}$ cells and RA CD4 ${ }^{+} \mathrm{T}$ cells were higher than those in normal $\mathrm{CD} 4^{+} \mathrm{T}$ cells (all $P<$ $0.05)$. However, there were no significant differences between SLE CD $4^{+} \mathrm{T}$ cells and RA CD $4^{+}$ $\mathrm{T}$ cells in the mRNA expressions of CD11a, CD70, CD40L after treated with same doses of $1.25(\mathrm{OH})_{2} \mathrm{D}_{3}$ (all $P>0.05$ ) (Fig. 4).

DNA methylation levels of CD11a, CD70 and CD4OL in CD4+ $T$ cells treated with different doses of $1,25(\mathrm{OH})_{2} D_{3}$

The Sodium Bisulfite sequencing results showed that DNA methylation levels in transcriptional regulation region of CD11a, CD70, and CD40L in normal/RA/SLE CD4+T cells increased with the increase doses of $1,25(\mathrm{OH})_{2} \mathrm{D}_{3^{*}}$. Compared with $\mathrm{CD} 4^{+} \mathrm{T}$ cells treated with 0

\section{KARGER}



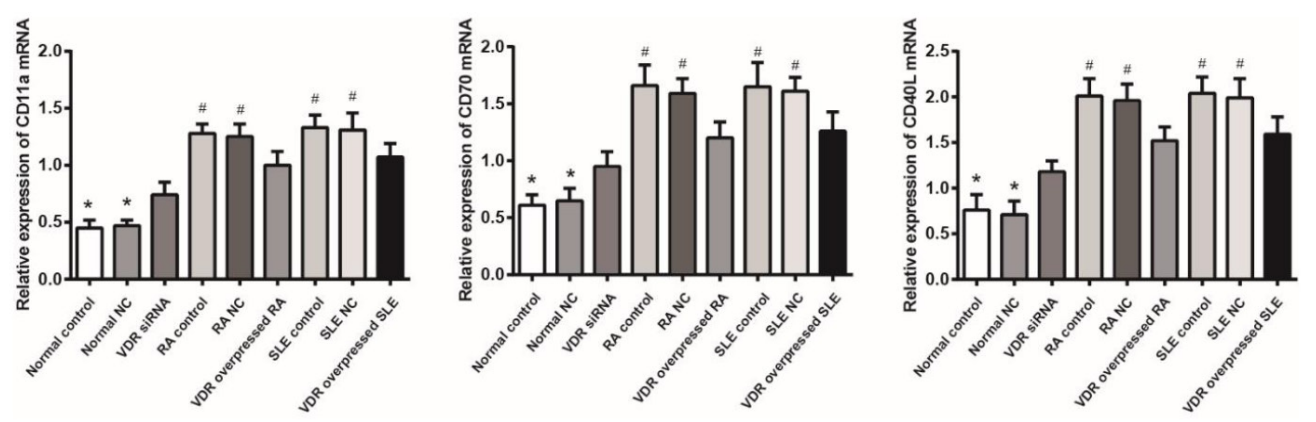

Fig. 7. The mRNA expressions of CD11a, CD70, and CD40L in CD4+ T cells after transfected with VDR overexpression vector and VDR siRNA vector. Note: * $P<0.05$ compared with the VDR siRNA group; \#, $P<0.05$ compared with the VDR overexpressed RA and overexpressed SLEA group.

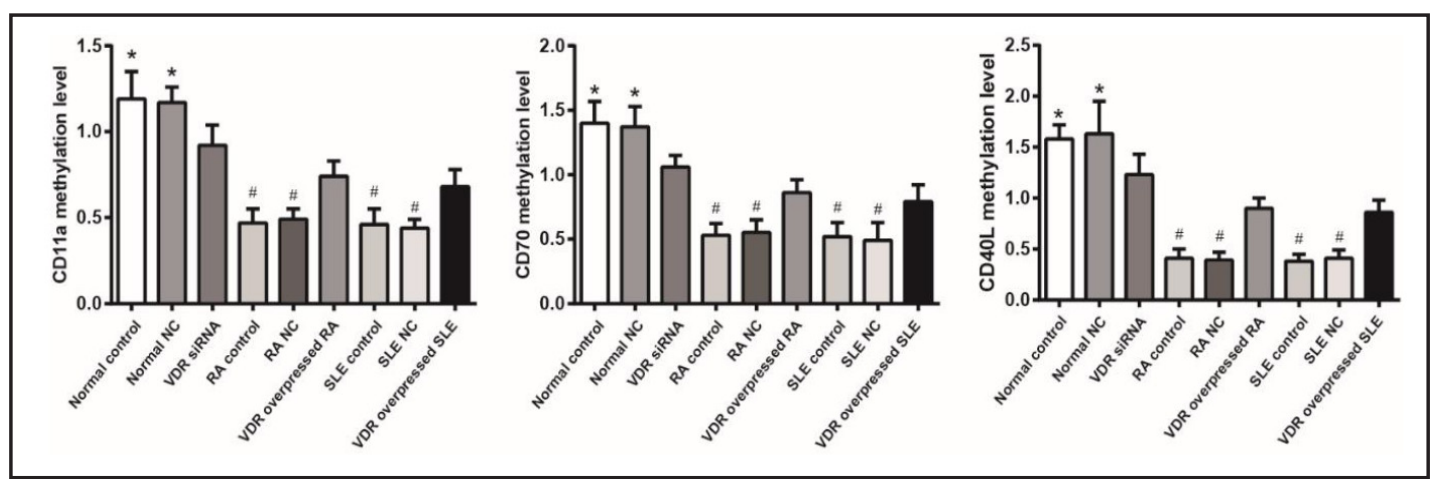

Fig. 8. DNA methylation levels in transcriptional regulation region of CD11a, CD70, and CD40L genes in $\mathrm{CD} 4{ }^{+} \mathrm{T}$ cells after transfected with VDR overexpression vector and VDR siRNA vector. Note: ${ }^{*}, P<0.05$ compared with the VDR siRNA group; \#, $P<0.05$ compared with the VDR overexpressed RA and overexpressed SLEA group.

$\mathrm{mol} / \mathrm{L} 1.25(\mathrm{OH})_{2} \mathrm{D}_{3}$, other doses of 1,25(OH)2D3 could significantly increase DNA methylation levels of CD11a, CD70, and CD40L. Among them, DNA methylation level was the highest at

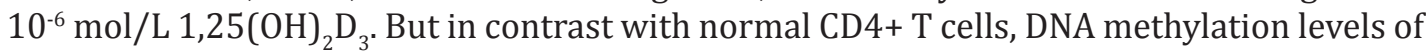
CD11a, CD70, and CD40L in SLE CD4 ${ }^{+} \mathrm{T}$ cells and RA CD4 ${ }^{+} \mathrm{T}$ cells were down-regulated (all $P<0.05)$. However, no significant difference was found in DNA methylation levels of CD11a, CD70, and CD40L between SLE CD4 ${ }^{+}$T cells and RA CD $4^{+}$T cells (all $P>0.05$ ) (Fig. 5).

Expressions of PKC $\delta$ and ERK1/2 in CD4 $4^{+}$T cells after transfected with VDR overexpression vector and VDR SiRNA vector

The VDR overexpression vectors were transfected into SLE CD4 ${ }^{+} \mathrm{T}$ cells and RA CD4 ${ }^{+}$ T cells. Compared with the SLE control, RA control, SLE NC and RA NC groups, the PKC $\delta$ and ERK1/2 expressions decreased in the VDR over-expressed SLE and VDR over-expressed RA groups (all $P<0.05$ ). VDR siRNA vectors were transfected into normal $\mathrm{CD}^{+}{ }^{+} \mathrm{T}$ cells. The PKC $\delta$ and ERK1/2 expressions in the VDR siRNA group were higher than those in the normal control group and normal NC group (all $P<0.05$ ). Furthermore, the PKC $\delta$ and ERK1/2 expressions in SLE CD4 ${ }^{+} \mathrm{T}$ cells and RA CD4 ${ }^{+} \mathrm{T}$ cells were higher than those in normal $\mathrm{CD} 4^{+} \mathrm{T}$ cells (all $P<0.05$ ). However, no significant difference was found in the expressions of PKC $\delta$ and ERK1/2 in SLE CD4 ${ }^{+} \mathrm{T}$ cells and RA CD4 ${ }^{+} \mathrm{T}$ cells (all $P>0.05$ ) (Fig. 6).

The mRNA expressions of CD11a, CD70, and CD4OL in CD4+ $T$ cells after transfected with VDR overexpression vector and VDR SiRNA vector

The results of RT-qPCR and flow cytometry illustrated that the expressions of CD11a, CD70 and CD40L reduced in the VDR over-expressed SLE and VDR over-expressed RA groups in comparison to the SLE control, RA group, SLE NC group and RA NC groups (all 
$P<0.05)$. The expressions of CD11a, CD70, and CD40L in the VDR siRNA group were higher than those in the normal control and normal NC groups (all $P<0.05$ ). In addition, the expressions of CD11a, CD70, and CD40L in SLE CD4+ $\mathrm{T}$ cells and RA CD4 ${ }^{+} \mathrm{T}$ cells were higher than those in normal CD4 ${ }^{+} \mathrm{T}$ cells (all $P<0.05$ ). However, no significant difference was found in the expressions of CD11a, CD70 and CD40L between SLE CD $4^{+} \mathrm{T}$ cells and RA CD4 ${ }^{+} \mathrm{T}$ cells (all $P>0.05$ ) (Fig. 7).

DNA methylation levels of CD11a, CD70, and CD40L genes in CD4+ ${ }^{+}$cells after transfected with VDR overexpression vector and VDR siRNA vector

The results of Sodium Bisulfite sequencing indicated that DNA methylation levels in transcription regulation region of methylation sensitive genes CD11a, CD70, and CD40L genes increased in the VDR over-expressed SLE and VDR over-expressed RA groups in comparison to the SLE control, RA control, SLE NC and RA NC groups (all $P<0.05$ ). DNA methylation levels of CD11a, CD70, and CD40L genes in the VDR siRNA group were lower than those in the normal control and normal NC groups (all $P<0.05$ ). Also, DNA methylation levels of CD11a, CD70, and CD40L genes in SLE CD4 ${ }^{+} \mathrm{T}$ cells and RA CD4 ${ }^{+} \mathrm{T}$ cells were lower than those in normal $C D 4^{+} \mathrm{T}$ cells (all $P<0.05$ ) However, no significant difference was found in DNA methylation levels of CD11a, CD70, and CD40L genes between SLE CD4+ $\mathrm{T}$ cells and RA CD $4^{+}$T cells (all $P>0.05$ ) (Fig. 8).

\section{Discussion}

SLE was a chronic and severe systemic autoimmune disease with heterogeneous clinical manifestations, which affected almost all organs of the body $[18,19]$. Although SLE risk of the genetic contribution was high, it was actually a genetically complex disease [20]. Therefore, an increased understanding of the genome structure could cause more discoveries that would be helpful to unravel the mechanisms involved [21].

In our study, we found that $1,25(\mathrm{OH})_{2} \mathrm{D}_{3}$ and VDR could play an important role in the activate regulation of $\mathrm{CD} 4^{+} \mathrm{T}$ cells and the SLE pathogenesis by mediating the PKC $\delta / E R K$ pathway, because serum $1,25(\mathrm{OH})_{2} \mathrm{D}_{3}$ levels and VDR expressions were significantly reduced in SLE patients. Also, inhibiting PKC /ERK pathway and increasing DNA methylation levels were conducive to inhibit the $\mathrm{CD} 4^{+} \mathrm{T}$ cells excessive activation so as to ease SLE autoimmune reaction. As the active form of vitamin, $1,25(\mathrm{OH})_{2} \mathrm{D}_{3}$ had anti-proliferative and pro-differentiation effects in many malignant cells, which could reduce the development and growth of tumors in preclinical models $[22,23]$. It was also found that $1,25(\mathrm{OH})_{2} \mathrm{D}_{3}$ could regulate the expression of many apoptosis factors or mediators and directly induce apoptosis through the activation of Caspase, which had been proved that it could reduce the immunostimulatory effects of the SLE $[24,25]$. Carvalho et al. had illustrated vitamin D, acting through VDR expressed in all immune cells, played an important role in the immune system homeostasis, and VDR polymorphisms and SLE had positive association [26]. In addition, some immunosuppressive effects were mediated by the interaction of hormone and nuclear receptor, and it had found that VDR could regulate gene expressions of sensitive tissues in vitamin D [27], which was consistent with our results. PKC $\delta$ was a serine kinase, being implicated in the control of cell proliferation and tissue remodeling [28]. Study had concluded that PKC $\delta$ deficiency could lead to a genetic defect of apoptosis leading to SLE, which accorded to our study [29]. ERK pathway was a kinase signaling cascade ubiquitously expressed in eukaryotic cells, which was initially thought to be primarily regulated by cell growth and proliferation, but was also believed to mediate inflammatory responses [30]. Being sufficient to cause SLE, CD $4^{+}$T cells from SLE patients showed ERK signaling pathway decreased and could result in changes of gene expression, which proved that environmentallymediated T cell PKC $\delta$ inactivation played a causative role in SLE. In addition, patients with active SLE could lead to the decrease of T cell methylation, which was consistent with our study result [31]. In addition, ERK1/2 was critical for T cell activation, therefore the 


\section{Cellular Physiology Cell Physiol Biochem 2016;40:743-756

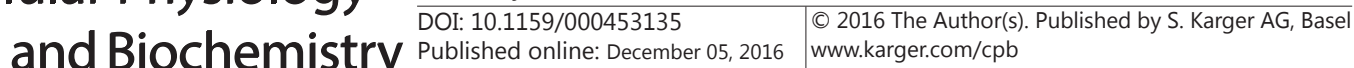 \\ He et al.: Roles of $1,25(\mathrm{OH})_{2} \mathrm{D}_{3}$ and VDR in RA and SLE}

methylation defect in T cells from SLE patients was traced to inhibit ERK pathway signaling [30], which proved our results from the side.

Our study also found that the increase doses of $1,25(\mathrm{OH})_{2} \mathrm{D}_{3}$ could increase DNA methylation levels of CD11a, CD70 and CD40L in SLE CD4 ${ }^{+} \mathrm{T}$ cells and decrease the expressions of PKC 8 , ERK1/2, CD11a, CD70 and CD40L. When SLE CD4+T cells were transfected with VDR overexpression vector, PKC $\delta$, ERK1/2, CD11a, CD70 and CD40L expressions decreased, but CD11a, CD70 and CD40L methylation levels increased; when normal CD4+T cells were transfected with VDR siRNA vector, PKC $\delta$, ERK1/2, CD11a, CD70 and CD40L expressions increased, but CD11a, CD70 and CD40L methylation levels decreased. Ivanova et al. pointed out that sera from SLE patients had differential immuno-reactivity to RNA, mitochondrial DNA (mtDNA) and total DNA, and mtDNA might play a vital role in the pathogenesis of SLE [32]. As the active form of vitamin $\mathrm{D}, 1,25(\mathrm{OH})_{2} \mathrm{D}_{3}$ was proved to regulate calcium and phosphate metabolism, cell differentiation, which had immunosuppressive effects [33]. Also, VDR was expressed in the mammary gland and vitamin D had been shown to display anticancer properties [34]. A previous study had concluded that with the increasing of serum $1,25(\mathrm{OH})_{2} \mathrm{D}_{3}$ level in human primary cell myoblasts, VDR expression could significantly increase [35]. It had been reported that CD40 stimulation was essential in the control of intracellular killing of pathogens and $1,25(\mathrm{OH})_{2} \mathrm{D}_{3}$ had been stimulated with the CD40L ligand. Therefore, $1,25(\mathrm{OH})_{2} \mathrm{D}_{3}$ could inhibit the expression of CD40 [36]. Also, VDR overexpression vector could reduce the activities of the collagen promoter in transfected cells [37]. Previous study had illustrated that evaluation of fibroblast VDR has revealed three general classes of molecular defects, and one was decreased or absent $1,25(\mathrm{OH})_{2} \mathrm{D}_{3}$ binding [38].

In conclusion, our study provide evidence that $1,25(\mathrm{OH})_{2} \mathrm{D}_{3}$ and VDR could inhibit the activation of $C D 4^{+} \mathrm{T}$ cells and suppress the immune response of SLE and RA through inhibiting PKC $\delta / E R K$ pathway and promoting DNA methylation of CD11a, CD70 and CD40L. However, the way of signal pathways to affect SLE and the measurements of CD11a, CD70 and CD40L were still unclear, more studies needed to be conducted.

\section{Acknowledgements}

The authors appreciate the reviewers for their useful comments in this paper.

\section{Disclosure Statement}

The authors declare no conflicts of interest.

\section{References}

1 Kyogoku C, Langefeld CD, Ortmann WA, Lee A, Selby S, Carlton VE, Chang M, Ramos P, Baechler EC, Batliwalla FM, Novitzke J, Williams AH, Gillett C, Rodine P, Graham RR, Ardlie KG, Gaffney PM, Moser KL, Petri M, Begovich AB, Gregersen PK, Behrens TW: Genetic association of the R620W polymorphism of protein tyrosine phosphatase PTPN22 with human SLE. Am J Hum Genet 2004;75:504-507.

2 Urbonaviciute V, Furnrohr BG, Meister S, Munoz L, Heyder P, De Marchis F, Bianchi ME, Kirschning C, Wagner H, Manfredi AA, Kalden JR, Schett G, Rovere-Querini P, Herrmann M, Voll RE: Induction of inflammatory and immune responses by HMGB1-nucleosome complexes: implications for the pathogenesis of SLE. J Exp Med 2008;205:3007-3018.

3 Gaipl US, Munoz LE, Grossmayer G, Lauber K, Franz S, Sarter K, Voll RE, Winkler T, Kuhn A, Kalden J, Kern P, Herrmann M: Clearance deficiency and systemic lupus erythematosus (SLE). J Autoimmun 2007;28:114121. 


\section{Cellular Physiology Cell Physiol Biochem 2016;40:743-756

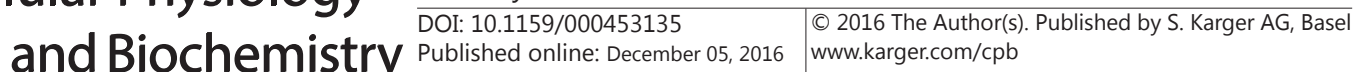 \\ He et al.: Roles of $1,25(\mathrm{OH})_{2} \mathrm{D}_{3}$ and VDR in RA and SLE}

4 Yu M, Song Y, Zhu MX, Liang W, Long Q, Ding PW, Xie Y, Liao YH, Yuan J: B10 Cells Ameliorate the Progression of Lupus Nephritis by Attenuating Glomerular Endothelial Cell Injury. Cell Physiol Biochem 2015;36:2161-2169.

5 Li F, Yang Y, Zhu X, Huang L, Xu J: Macrophage Polarization Modulates Development of Systemic Lupus Erythematosus. Cell Physiol Biochem 2015;37:1279-1288.

6 Seavey MM, Lu LD, Stump KL: Animal models of systemic lupus erythematosus (SLE) and ex vivo assay design for drug discovery. Curr Protoc Pharmacol 2011; Chapter 5:Unit 5.60.

7 Yang Y, Chung EK, Wu YL, Savelli SL, Nagaraja HN, Zhou B, Hebert M, Jones KN, Shu Y, Kitzmiller K, Blanchong CA, McBride KL, Higgins GC, Rennebohm RM, Rice RR, Hackshaw KV, Roubey RA, Grossman JM, Tsao BP, Birmingham DJ, Rovin BH, Hebert LA, Yu CY: Gene copy-number variation and associated polymorphisms of complement component C4 in human systemic lupus erythematosus (SLE): low copy number is a risk factor for and high copy number is a protective factor against SLE susceptibility in European Americans. Am J Hum Genet 2007;80:1037-1054.

8 McInnes IB, Schett G: The pathogenesis of rheumatoid arthritis. N Engl J Med 2011;365:2205-2219.

9 Pernis AB: Th17 cells in rheumatoid arthritis and systemic lupus erythematosus. J Intern Med 2009;265:644-652.

10 Fujii Y, Fujii K, Tanaka Y: Attempt to correct abnormal signal transduction in T lymphocytes from systemic lupus erythematosus patients. Autoimmun Rev 2006;5:143-144.

11 Azab NA, Bassyouni IH, Emad Y, Abd El-Wahab GA, Hamdy G, Mashahit MA: CD4+CD25+ regulatory T cells (TREG) in systemic lupus erythematosus (SLE) patients: the possible influence of treatment with corticosteroids. Clin Immunol 2008;127:151-157.

12 Huhtakangas JA, Olivera CJ, Bishop JE, Zanello LP, Norman AW: The vitamin D receptor is present in caveolae-enriched plasma membranes and binds 1 alpha,25(OH)2-vitamin D3 in vivo and in vitro. Mol Endocrinol 2004;18:2660-2671.

13 Gorjestani S, Rider V, Kimler BF, Greenwell C, Abdou NI: Extracellular signal-regulated kinase 1/2 signalling in SLE T cells is influenced by oestrogen and disease activity. Lupus 2008;17:548-554.

14 Sipka S: Adenosine inhibits the release of arachidonic acid in activated human peripheral mononuclear cells. A proposed model for physiologic and pathologic regulation in systemic lupus erythematosus. ScientificWorldJournal 2011;11:972-980.

15 Lin CW, Hou WC, Shen SC, Juan SH, Ko CH, Wang LM, Chen YC: Quercetin inhibition of tumor invasion via suppressing PKC delta/ERK/AP-1-dependent matrix metalloproteinase- 9 activation in breast carcinoma cells. Carcinogenesis 2008;29:1807-1815.

16 Hochberg MC: Updating the American College of Rheumatology revised criteria for the classification of systemic lupus erythematosus. Arthritis Rheum 1997;40:1725.

17 Kay J, Upchurch KS: ACR/EULAR 2010 rheumatoid arthritis classification criteria. Rheumatology (Oxford) 2012;51:vi5-9.

18 Ramos PS, Criswell LA, Moser KL, Comeau ME, Williams AH, Pajewski NM, Chung SA, Graham RR, Zidovetzki R, Kelly JA, Kaufman KM, Jacob CO, Vyse TJ, Tsao BP, Kimberly RP, Gaffney PM, Alarcon-Riquelme ME, Harley JB, Langefeld CD, International Consortium on the Genetics of Systemic E: A comprehensive analysis of shared loci between systemic lupus erythematosus (SLE) and sixteen autoimmune diseases reveals limited genetic overlap. PLoS Genet 2011;7:e1002406.

19 Yaniv G, Twig G, Shor DB, Furer A, Sherer Y, Mozes O, Komisar O, Slonimsky E, Klang E, Lotan E, Welt M, Marai I, Shina A, Amital H, Shoenfeld Y: A volcanic explosion of autoantibodies in systemic lupus erythematosus: a diversity of 180 different antibodies found in SLE patients. Autoimmun Rev 2015;14:7579.

20 Morris DL, Roberts AL, Witherden AS, Tarzi R, Barros P, Whittaker JC, Cook TH, Aitman TJ, Vyse TJ: Evidence for both copy number and allelic (NA1/NA2) risk at the FCGR3B locus in systemic lupus erythematosus. Eur J Hum Genet 2010;18:1027-1031.

21 Fanciulli M, Norsworthy PJ, Petretto E, Dong R, Harper L, Kamesh L, Heward JM, Gough SC, de Smith A, Blakemore AI, Froguel P, Owen CJ, Pearce SH, Teixeira L, Guillevin L, Graham DS, Pusey CD, Cook HT, Vyse TJ, Aitman TJ: FCGR3B copy number variation is associated with susceptibility to systemic, but not organspecific, autoimmunity. Nat Genet 2007;39:721-723. 


\section{Cellular Physiology Cell Physiol Biochem 2016;40:743-756 \begin{tabular}{l|l|l}
\hline DOI: 10.1159/000453135 & $\begin{array}{l}\text { (c) 2016 The Author(s). Published by S. Karger AG, Basel } \\
\text { www.karger.com/cpb }\end{array}$
\end{tabular} \\ He et al.: Roles of $1,25(\mathrm{OH})_{2} \mathrm{D}_{3}$ and VDR in RA and SLE}

22 Min D, Lv XB, Wang X, Zhang B, Meng W, Yu F, Hu H: Downregulation of miR-302c and miR-520c by 1,25(OH)2D3 treatment enhances the susceptibility of tumour cells to natural killer cell-mediated cytotoxicity. Br J Cancer 2013;109:723-730.

23 Trump DL, Deeb KK, Johnson CS: Vitamin D: considerations in the continued development as an agent for cancer prevention and therapy. Cancer J 2010;16:1-9.

24 Kizildag S, Ates H, Kizildag S: Treatment of K562 cells with 1,25-dihydroxyvitamin D3 induces distinct alterations in the expression of apoptosis-related genes BCL2, BAX, BCLXL, and p21. Ann Hematol 2010;89:1-7.

25 Lerman M, Burnham J, Behrens E: 1,25 dihydroxyvitamin D3 limits monocyte maturation in lupus sera. Lupus 2011;20:749-753.

26 Carvalho C, Marinho A, Leal B, Bettencourt A, Boleixa D, Almeida I, Farinha F, Costa PP, Vasconcelos C, Silva BM: Association between vitamin D receptor (VDR) gene polymorphisms and systemic lupus erythematosus in Portuguese patients. Lupus 2015;24:846-853.

27 Munoz LE, Schiller M, Zhao Y, Voll RE, Schett G, Herrmann M: Do low vitamin D levels cause problems of waste removal in patients with SLE? Rheumatology (Oxford) 2012;51:585-587.

28 Steinberg SF: Distinctive activation mechanisms and functions for protein kinase Cdelta. Biochem J 2004;384:449-459.

29 Belot A, Kasher PR, Trotter EW, Foray AP, Debaud AL, Rice GI, Szynkiewicz M, Zabot MT, Rouvet I, Bhaskar SS, Daly SB, Dickerson JE, Mayer J, O'Sullivan J, Juillard L, Urquhart JE, Fawdar S, Marusiak AA, Stephenson N, Waszkowycz B, M WB, Biesecker LG, G CMB, Rene C, Eliaou JF, Fabien N, Ranchin B, Cochat P, Gaffney PM, Rozenberg F, Lebon P, Malcus C, Crow YJ, Brognard J, Bonnefoy N: Protein kinase cdelta deficiency causes mendelian systemic lupus erythematosus with B cell-defective apoptosis and hyperproliferation. Arthritis Rheum 2013;65:2161-2171.

30 Gorelik G, Richardson B: Key role of ERK pathway signaling in lupus. Autoimmunity 2010;43:17-22.

31 Gorelik G, Sawalha AH, Patel D, Johnson K, Richardson B: T cell PKCdelta kinase inactivation induces lupuslike autoimmunity in mice. Clin Immunol 2015;158:193-203.

32 Ivanova VV, Khaiboullina SF, Cherenkova EE, Martynova EV, Nevzorova TA, Kunst MA, Sibgatullin TB, Maksudova AN, Oliveira PJ, Lombardi VC, Palotas A, Rizvanov AA: Differential immuno-reactivity to genomic DNA, RNA and mitochondrial DNA is associated with auto-immunity. Cell Physiol Biochem 2014;34:2200-2208.

33 Ciesielski F, Rochel N, Mitschler A, Kouzmenko A, Moras D: Structural investigation of the ligand binding domain of the zebrafish VDR in complexes with 1alpha,25(OH)2D3 and Gemini: purification, crystallization and preliminary X-ray diffraction analysis. J Steroid Biochem Mol Biol 2004;89-90:55-59.

34 Lopes N, Sousa B, Martins D, Gomes M, Vieira D, Veronese LA, Milanezi F, Paredes J, Costa JL, Schmitt F: Alterations in Vitamin D signalling and metabolic pathways in breast cancer progression: a study of VDR, CYP27B1 and CYP24A1 expression in benign and malignant breast lesions. BMC Cancer 2010;10:483.

35 Pojednic RM: The Role of the Vitamin D Receptor in Aging Skeletal Muscle and Inflammatory Response. Dissertations \& Theses - Gradworks 2014; 109 pages;3623914.

36 Almerighi C, Sinistro A, Cavazza A, Ciaprini C, Rocchi G, Bergamini A: 1Alpha,25-dihydroxyvitamin D3 inhibits CD40L-induced pro-inflammatory and immunomodulatory activity in human monocytes. Cytokine 2009;45:190-197.

37 Potter JJ, Liu X, Koteish A, Mezey E: 1,25-dihydroxyvitamin D3 and its nuclear receptor repress human alpha1 (I) collagen expression and type I collagen formation. Liver Int 2013;33:677-686.

38 Ritchie HH, Hughes MR, Thompson ET, Malloy PJ, Hochberg Z, Feldman D, Pike JW, O'Malley BW: An ochre mutation in the vitamin D receptor gene causes hereditary 1,25-dihydroxyvitamin D3-resistant rickets in three families. Proc Natl Acad Sci USA 1989;86:9783-9787. 
In the original article by He et al. entitled "Roles of $1,25(\mathrm{OH})_{2} \mathrm{D}_{3}$ and Vitamin D Receptor in the Pathogenesis of Rheumatoid Arthritis and Systemic Lupus Erythematosus by Regulating the Activation of CD4+ T Cells and the PKC $\delta /$ ERK Signaling Pathway" [Cell Physiol Biochem 2016;40:743-756 (DOI: 10.1159/000453135)] is necessary for authors to add the funding:

"This study was supported by a grant from National Natural Science Foundation of China (No. 81560275), Social Development Science and Technology Special Project of Hainan Province (No. 2015SF39) and Association for Science and Technology Youth Science and Technology Academic Excellence Innovation Project of Hainan Province (No. 201515)."

The authors terribly apologized for this carelessness. 